\title{
Analisis Kinerja VHF-A/G Tower/ADC dengan VHF-A/G APP di Bandar Udara Husein Sastranegara Bandung
}

\author{
Adisty Hanny Asri ${ }^{1}$, Lita Lidyawati ${ }^{2}$ \\ ${ }^{1,2}$ Jurusan Teknik Elektro Institut Teknologi Nasional Bandung \\ adisty.hanny@gmail.com ${ }^{1}$
}

\begin{abstract}
Abstrak- Penelitian ini menjelaskan kinerja komunikasi penerbangan dari perangkat VHF-A/G antara ADC/TOWER (Aerodrome Control) maupun APP (Approach Control Center) dengan pilot di pesawat. Jika terjadi kesalahan dalam pengaturan wilayah pada kedua ruang lingkup udara tersebut, tidak dapat terjadi komunikasi yang diharapkan, pilot dapat kehilangan arah dalam menentukan tujuan. ATC(Air Traffic Control) memandu seluruh kegiatan penerbangan dengan pilot di pesawat dengan bantuan navigator. VHF A/G memiliki batas frekuensi 118- $137 \mathrm{MHz}$, daya yang dipancarkan antara 25 Watt sampai dengan 50 Watt dengan ketinggian $0-20000 \mathrm{ft}$ dan jarak jangkauan $0-87 \mathrm{Nm}$. Penggunaan perangkat VHF-A/G untuk melakukan komunikasi dengan baik antara pilot di pesawat dengan ATC diukur dengan indikator level, yang menunjukkan kondisi perangkat VHF-A/G dibagian pengirim dan penerima. Pesawat dengan level readability (keterbacaan) terbaik yaitu 4 dan 5 diantaranya; Citylink Air 888, Garuda, Air Asia, Lion Air 911 dan 903, Auri (Militer), Express Air, Red Cap Air dan Wings Air.
\end{abstract}

Kata Kunci: VHF-A/G, ADC/TOWER (Aerodrome Control), APP (Approach Control Center), Indikator Level Keterbacaan

\section{Pendahuluan}

AirNav Indonesia merupakan BUMN Indonesia yang bergerak di bidang usaha pelayanan navigasi udara berdasarkan PP No.77 Tahun 2012, bertekad untuk menjadi penyelenggara pelayanan navigasi penerbangan dengan Standar Internasional yang mengedepankan keselamatan, keteraturan dan kenyamanan[6].

Saat ini, sistem manajemen lalu lintas udara terutama menggunakan komunikasi udara-kedarat (Air to Ground) di pita VHF (mis., 118-137 MHz). Sistem ini menyediakan layanan suara dan data yang penting dalam komunikasi aeronautika antara pengendali ATC dan pilot[1,2,7].

Sistem Manajemen Lalu Lintas Udara (ATM) atau Air Traffic Management sangat bergantung pada komunikasi darat. Band frekuensi yang saat ini digunakan untuk komunikasi air to ground (117.975 - $137.000 \mathrm{MHz}$ ) menjadi padat bahkan di beberapa bagian Eropa, memang sulit untuk menemukan frekuensi yang memungkinkan untuk menjalankan tugas seputar kegiatan penerbangan. Sehingga pelayanan komunikasi sistem ATM seperti konsep sistem operasional serta perbandingan rentang spektrum dan komunikasi yang berbeda pada mekanisme yang digunakan dalam lapisan data fisik dan data teknologi aeronautika penting dilakukan[3].

Sumber frekuensi untuk wide-band di masa depan, mengenai sistem komunikasi di Air Traffic Control (ATC) pada tingkat lanjut bandara telah menjadi isu vital industri penerbangan. Saluran udara-ke-darat (Air to Ground) dapat memiliki karakteristik band baru dan lebar dalam 5 $\mathrm{GHz}$, untuk komunikasi ATC dalam segala periode saat pesawat berada di dekat pesawat bandara dengan eksperimen dan pengukuran yang praktis, termasuk lepas landas/ mendarat[4].

TELKA, Vol.4, No.1, Mei 2018, pp. 76 85

ISSN (e): 2540-9123

ISSN (p): 2502-1982 
Selain itu, peningkatan propagasi ada dari pesawat ke salah satu terminal untuk sebagian besar waktu operasional mempengaruhi performa sistem yang digunakan. Hal ini menunjukkan bahwa banyak sistem udara-ke-darat VHF-A/G yang ada dunia dapat diperpanjang hingga setidaknya 500 mile. Daya efektif dan situs antena tinggi untuk kinerja yang semakin baik[5].

Adapun peralatan telekomunikasi penerbangan yang terdapat di Bandar Udara Husein Sastranegara Bandung diantaranya AMSC (Automatic Message Switching Control), VHF-ER (Very High Frequency - Extended Range), VHF-A/G (Very High Frequency-Air to Ground), VSCS (Voice Switching Communication System), Recorder, dan D- ATIS (Digital-Automatic Terminal Information System) sedangkan untuk peralatan Navigasi Udara terdiri dari NDB (Non Directional Beacon), DVOR (Doppler VHF Omnidirectional Range), dan DME (Distance Measuring Equipment). Seluruh peralatan tersebut mengatur ruang lingkup udara ADC/TOWER dan APP.

Fasilitas-fasilitas keselamatan penerbangan harus dalam posisi hidup selama $24 \mathrm{jam}$. Hal ini untuk memberikan pelayanan terhadap lalu lintas udara yang datang dan pergi serta overflying. Jika terjadi kesalahan dalam pengaturan wilayah pada kedua ruang lingkup udara ADC/TOWER dan APP, tidak dapat terjadi komunikasi yang diharapkan dan pilot dapat kehilangan arah dalam menentukan tujuan. Sehubungan dengan hal tersebut dalam penelitian ini mengambil salah satu alat untuk dibahas yaitu radio pemancar VHF-A/G dengan judul laporan Analisis Kinerja VHFA/G ADC/Tower dengan VHF-A/G APP di Bandar Udara Husein Sastranegara Bandung.

\section{Metodologi Penelitian}

\subsection{Blok Diagram Pengirim dan Penerima VHF-A/G}

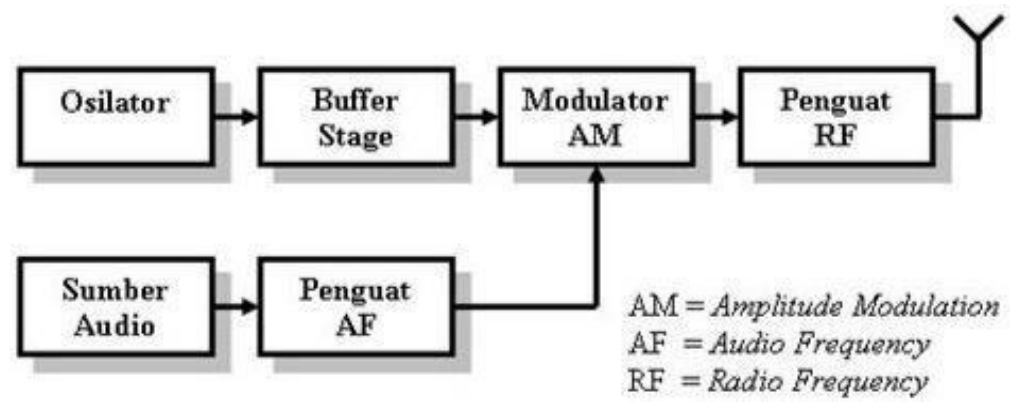

Gambar 1. Blok Diagram Pengirim VHF-A/G

Osilator adalah suatu rangkaian elektronika yang menghasilkan sejumlah getaran atau sinyal listrik secara periodik dengan amplitudo yang konstan. Rangkaian osilator sederhana terdiri dari dua bagian utama, yaitu Penguat (Amplifier) dan Umpan Balik (Feedback) dihubungkan dengan Buffer Stage (penyangga/penyaring) sinyal masukan agar sesuai dengan karakteristik kerja penguat yang berfungsi menguatkan arus sinyal keluaran dari osilator.

Ciri buffer:

a) Daya outputnya kecil

b) Impedansi input tinggi yang pembebanan yang rendah dari tingkat sebelumnya

c) Impedansi output rendah

d) Jika buffer tidak digunakan, maka transfer daya dari tingkat sebelumnya ke tingkat selanjutnya tidak akan maksimum.

Selanjutnya, dari buffer masuk ke modulator AM, terjadi proses menumpangkan sinyal informasi ke sinyal pembawa (carrier) sehingga amplituda gelombang pembawa berubah sesuai dengan perubahan simpangan (tegangan) sinyal informasi, amplituda sinyal pembawa diubah- 
ubah secara proporsional terhadap amplituda sesaat sinyal pemodulasi, sedangkan frekuensinya tetap. Sumber audio yang dikuatkan dengan penguat AF dihubungkan pula ke modulator AM dan sinyal keluarannya dikuatkan dengan penguat RF yaitu berfungsi memperkuat sinyal frekuensi tinggi yang dihasilkan osilator RF dan diterima oleh antena untuk dipancarkan ke antena penerima dipesawat.

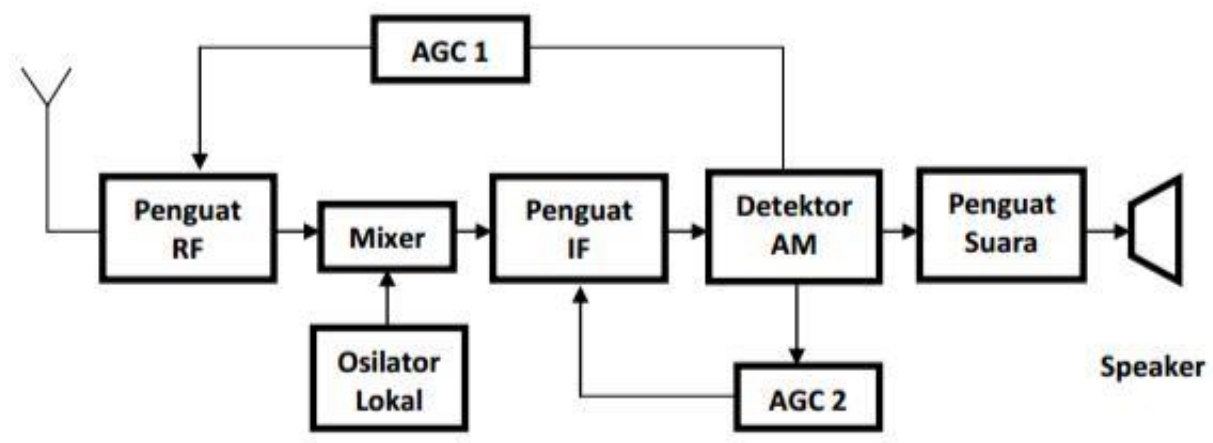

Gambar 2. Blok Diagram Penerima VHF-A/G

Antena akan menangkap getaran atau sinyal yang membawa/berisi informasi yang dipancarkan oleh pemancar. Sinyal tersebut akan dikuatkan oleh penguat RF untuk menguatkan daya RF (Radio Frequency/ frekuensi tinggi) yang berisi informasi sebagai hasil modulasi pemancar asal. Setelah diperkuat, getaran RF dicatukan ke mixer. Mixer akan mencampurkan sinyal RF dengan frekuensi osilator lokal, sehingga diperoleh frekuensi intermediet (IF/Intermediate Frequency). Penguat IF berfungsi untuk menguatkan Frekuensi Intermediet (IF) sebelum diteruskan ke blok detektor. IF merupakan hasil dari pencampuran sinyal antara RF dengan osilator lokal. Kemudian dihubungkan ke detektor yaitu untuk mengubah frekuensi IF menjadi frekuensi informasi. Dengan cara ini, unit detektor memisahkan antara sinyal pembawa RF dengan sinyal informasi (Audio Frequency/AF) . Penguat suara AF berfungsi untuk menyearahkan sinyal AF serta meningkatkan level sinyal audio dan kemudian diteruskan penguat AF ke suatu pengeras suara atau speaker untuk mengubah sinyal atau getaran listrik berfrekuensi AF menjadi getaran suara yang dapat didengar oleh telinga manusia. AGC Detector (Automatic Gain Control/ Pengendali Penguatan Otomatis) berfungsi untuk mengatur tegangan output secara otomatis agar tetap stabil.

\subsection{Karakteristik VHF-A/G}

VHF-A/G yang merupakan radio pemacar bekerja secara terus menerus 24 jam per hari berfungsi sebagai media komunikasi antara pilot di pesawat terbang dengan ATC (Air Traffic Control) pada jangkauan tertentu. ATC akan menghubungi pesawat untuk memberi atau menanyakan suatu informasi dan pesawat akan menjawab atau memberitahukan kepada ATC secara bergantian melalui indikator jarak dari antena DVOR yang disebut DME (Distance Measure Equipment). Ketinggian APP pada $10.000 \mathrm{ft}-20.000 \mathrm{ft}$ dan ADC/Tower $0 \mathrm{ft}-10.000$ $\mathrm{ft}$. Pesawat yang terbang ada pada ketinggian diatas $\pm 15.000 \mathrm{ft}$ atau di atas awan dengan daya pancar 100 Watt.

Alat VHF-A/G yang berada dipesawat dapat mengalami kerusakan, artinya komunikasi yang terjadi antara ATC dengan Pilot tidak berjalan dengan baik yang bisa disebabkan karena perangkat, maupun gangguan dari luar yang muncul. Hal tersebut dapat dilihat dari hasil pengecekan readability berupa level dari 1 sampai dengan 5 yang dapat terbaca oleh pilot. Semakin tinggi level readability, maka semakin baik kualitas/kinerja alat VHF-A/G, apabila semakin rendah level readability, maka semakin buruk kualitas/kinerja alat tersebut. 

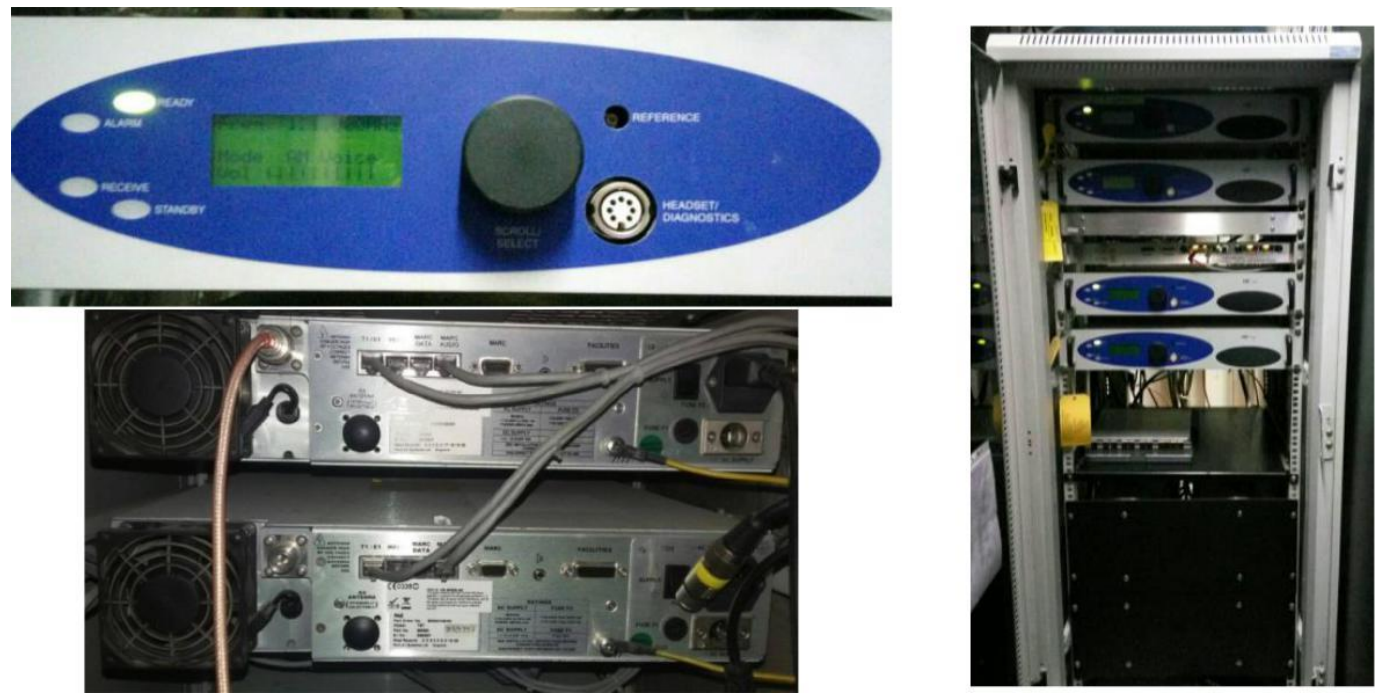

Gambar 3. Perangkat VHF-A/G

\subsection{Blok Diagram Interkoneksi General VHF-A/G ADC}

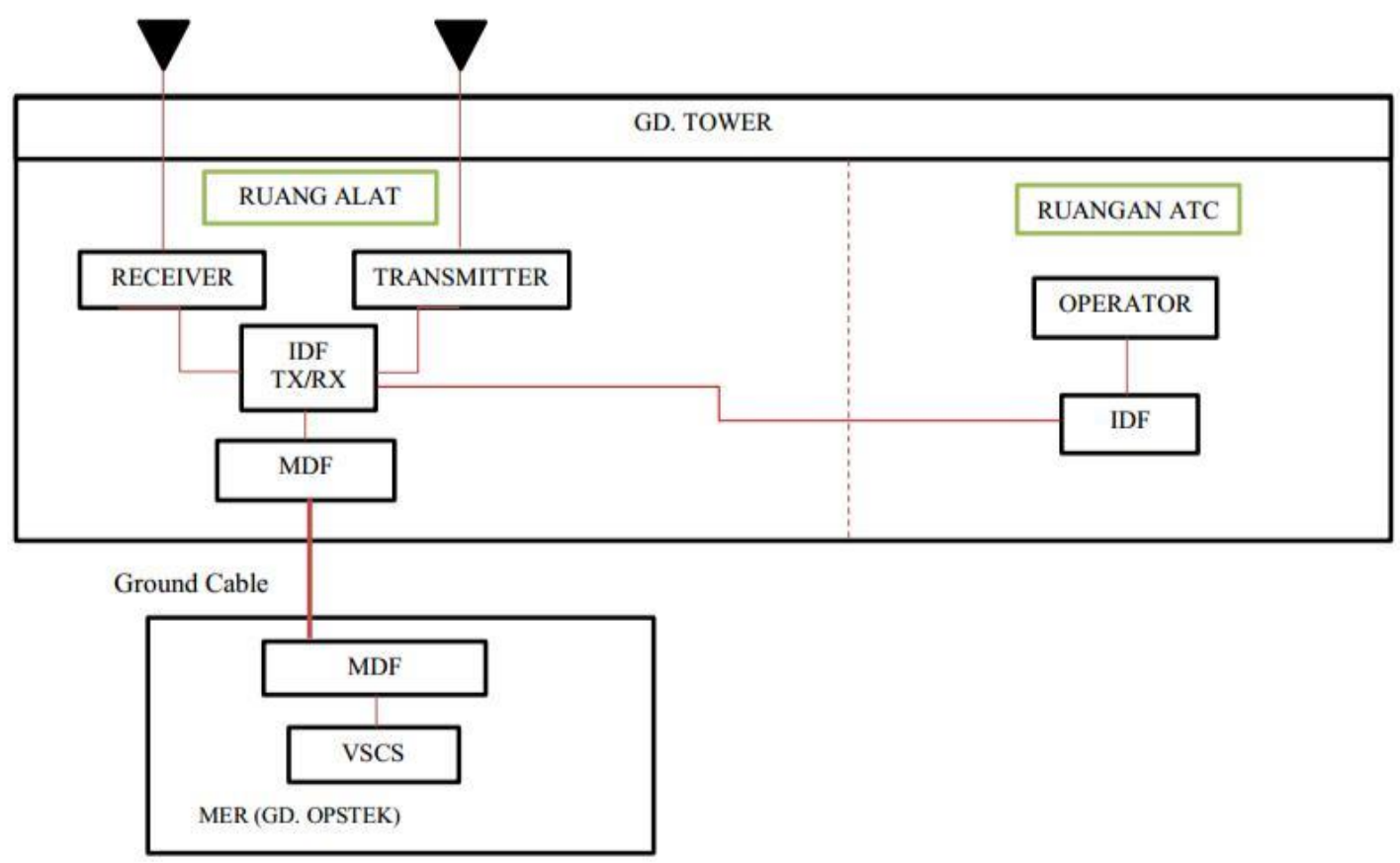

Gambar 4. Blok Diagram Interkorelasi VHF-A/G ADC/TOWER

Di dalam gedung ADC/TOWER terdapat dua ruangan yang berperan penting dalam melakukan kontrol komunikasi darat ke udara maupun udara ke darat. Ruangan pertama adalah ruang alat, diantaranya terdapat antena pemancar dan penerima yang terhubung ke IDF. IDF (Intermediate Distribution Frame) berupa kron distribusi (terminal).

VHF -A/G TX dan RX terhubung ke beberapa alat lain, yaitu VSCS dan Voice Recorder maka dari itu VHF-A/G dihubungkan secara paralel dengan kabel di alat (VSCS dan Voice 
recorder) pada IDF. Selain itu dapat mempermudah instalasi penggunaan di radio pemancar dan penerima VHF-A/G.

Kemudian, IDF di ruang alat terhubung dengan IDF di ruang kedua yaitu ruangan ATC, fungsinya untuk mempermudah operator mengontrol komunikasi dengan pesawat tanpa harus melakukannya di ruang alat. IDF ini berskala lebih dari MDF, baik dari segi fisik panel maupun pelayanan distribusinya, karena hanya menglingkupi pembagian area atau blok tertentu sesuai dengan struktur bangunan itu sendiri misalnya pada hotel dibagi ke sub back area, guest area, office area, area per level gedung dan khususnya pada area penerbangan.

Dari IDF ruang alat terhubung dengan MDF (Main Distribution Frame) adalah frame/panel utama untuk terminasi/penyambungan instalasi PABX. Pada frame/panel ini terdapat sistem terminasi instalasi sebelum di distribusikan ke pembagian instalasi telepon gedung. Dalam panel MDF, pembagian -pembagian inti disusun, salah satunya dari perangkat radio pemancar VHF A/G ke alat-alat yang berhubungan, yaitu VSCS dan recorder. Dari MDF ruang alat di gedung ADC/TOWER, terhubung dengan MDF digedung MER (Main Equipment Room) memiliki fungsi yang sama. MER merupakan tempat pendinginan seluruh alat-alat komunikasi penerbangan beroperasi selama 24 jam. Seluruh kegiatan komunikasi penerbangan dapat terdengar melalui peralatan diruangan ini.

\subsection{Blok Diagram Interkoneksi General VHF-A/G APP}

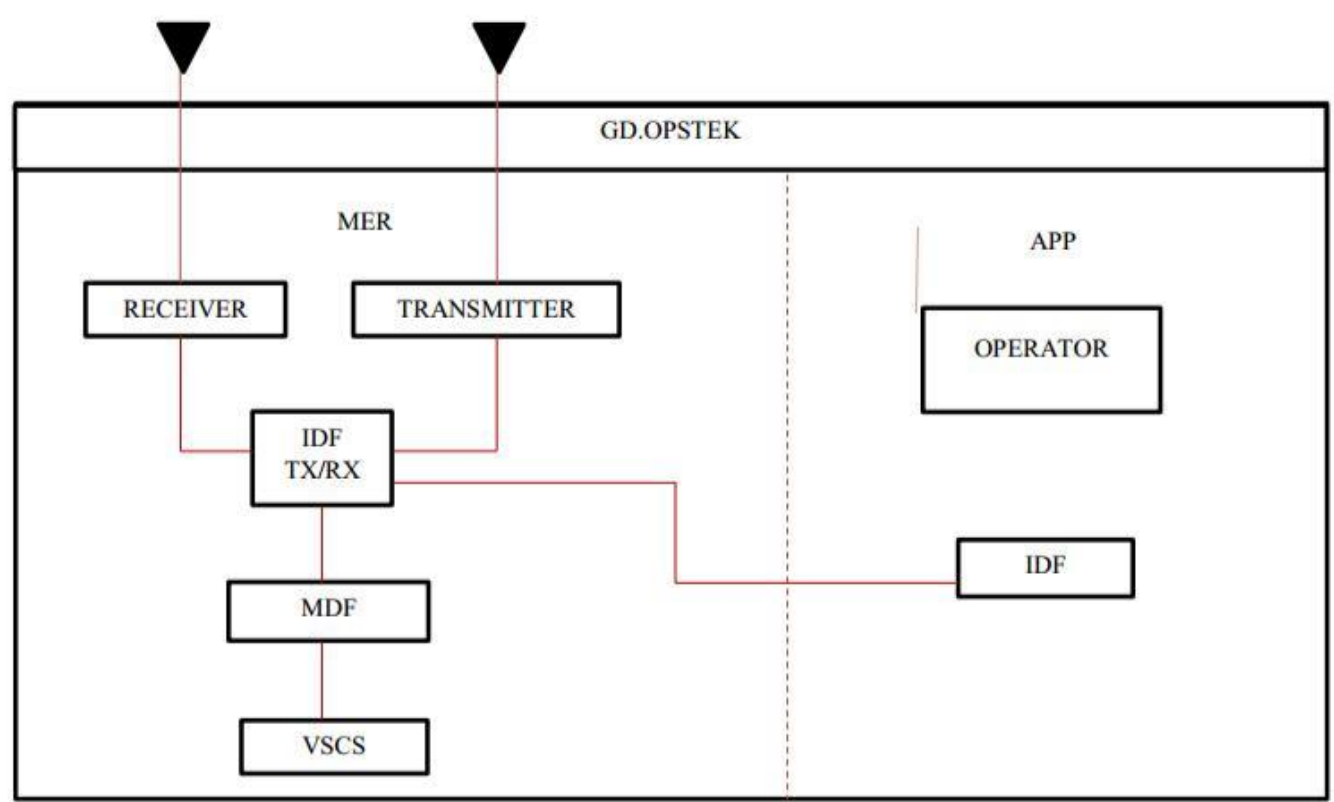

Gambar 5. Blok Diagram Interkorelasi VHF-A/G APP

Di dalam gedung Opstek (Operasional Technique) terdapat dua ruangan. Ruangan pertama adalah MER (Main Equipment Room), merupakan ruang seluruh alat komunikasi penerbangan beroperasi. Interkoneksinya dari VSCS terhubung ke MDF, supaya memudahkan operator dalam memilih alat yang akan digunakan. MDF merupakan panel utama untuk terminasi/penyambungan instalasi PABX. Peralatan mampu pindah secara otomatis ke peralatan standby bila terjadi kerusakan pada peralatan main dan dapat pindah secara remote bila diperlukan. Peralatan VHF dapat dikendalikan/remote dari desk operator atau communication desk melalui display VSCS Peralatan VHF harus terintegrasi dengan VSCS dan Digital Voice Recorder.

Pada panel ini terdapat sistem terminasi instalasi sebelum di distribusikan ke pembagian instalasi telepon gedung kemudian dihubungkan ke IDF TX RX. IDF TX RX berupa kron 
distribusi (terminal) untuk disambungkan ke antenna pemancar dan penerima VHF-A/G. IDF yang berada di ruang MER dihubungan dengan IDF yang berada di ruangan kedua yaitu ruang APP, untuk memudahkan operator mengontrol dan melakukan komunikasi dengan pesawat.

Cara pengontrolan ADC/TOWER dan APP pada pesawat berbeda, pada wilayah ADC/TOWER dapat dilakukan kontrol secara langsung dengan pesawat hanya memastikan keadaan landasan sudah siap untuk pendaratan pesawat sedangkan pada wilayah APP pengontrolan pesawat terjadi pada navigasi VOR-DME. Hal ini disebabkan karena jarak jangkauannya jauh, sehingga pesawat yang akan mendarat harus melalui titik acuan lebih dahulu yaitu pada VOR- DME yang berbeda lokasi dengan ATC. Tujuannya supaya navigator dapat mengarahkan pilot menuju APP dalam proses take off. Setelah itu, diambil alih oleh pengontrol APP.

\section{Hasil Dan Pembahasan}

\subsection{Daya yang dipancarkan dari antena VHF-A/G ke Pesawat}

Tabel 1. Daya yang Dipancarkan dari Antena VHF-A/G

\begin{tabular}{|l|c|c|}
\hline & ADC/Tower & APP \\
\hline Daya (Watt) & $25-30$ & $30-50$ \\
\hline
\end{tabular}

Daya yang dipancarkan oleh antena VHF-A/G ke pesawat ketika berada pada wilayah ADC/TOWER adalah kisaran 25-30 Watt. Daya 25-30 Watt diperoleh ketika pesawat, terbang pada jarak tertentu menjauhi antena pemancar dan masih berada di wilayah ADC/TOWER. Sedangkan daya yang dipancarkan oleh VHF-A/G ke pesawat ketika berada di wilayah APP adalah 30-50 Watt. Hal ini disebabkan karena wilayah APP berada pada lapisan udara troposfer.

\subsection{Ketinggian pesawat yang di kontrol ADC/TOWER dan APP}

Tabel 2. Ketinggian Wilayah Kontrol ADC/TOWER dan APP

\begin{tabular}{|c|c|c|}
\hline & ADC/Tower & APP \\
\hline Ketinggian $(\mathrm{ft})$ & $0-10000$ & $10000-20000$ \\
\hline Ketinggian $(\mathrm{km})$ & $0-3,048$ & $3,048-6,096$ \\
\hline
\end{tabular}

Pengontrolan kinerja komunikasi oleh ATC pada VHF-A/G dapat dilakukan di wilayah ADC/TOWER dan APP ketika pesawat berada pada ketinggian mulai dari $0 \mathrm{ft}$ yaitu masih berada dilandasan atau di Apron ('garasi pesawat') hingga altitude $10000 \mathrm{ft}$. Altitude untuk pesawat, terbang pada ketinggian 1000-10000 ft dan Flight level untuk pesawat, terbang pada ketinggian diatas $10000 \mathrm{ft}$.

\subsection{Jangkauan Kontrol Jarak Pesawat oleh ADC/TOWER dan APP}

Tabel 3. Jarak Jangkau Wilayah Kontrol ADC/TOWER dan APP

\begin{tabular}{|c|c|c|}
\hline & ADC/Tower & APP \\
\hline Jarak $(\mathrm{Nm})$ & $0-40$ & $40-87$ \\
\hline Jarak $(\mathrm{km})$ & $0-74,08$ & $74,08-161,124$ \\
\hline
\end{tabular}

Keterangan: $1 \mathrm{Nm}=1.852 \mathrm{~km}$

Pengontrolan VHF-A/G dapat dilakukan di wilayah ADC/TOWER dan APP ketika pesawat berada pada jarak jangkauan mulai dari $0 \mathrm{Nm}$ hingga $40 \mathrm{Nm}$ hanya untuk wilayah ADC/TOWER. Pada jangkauan lebih dari $40 \mathrm{Nm}$ hingga $87 \mathrm{Nm}$ kendali kontrol sudah dialihkan oleh APP. 


\subsection{Pengecekan Sistem Komunikasi pada VHF-A/G ADC di Pesawat}

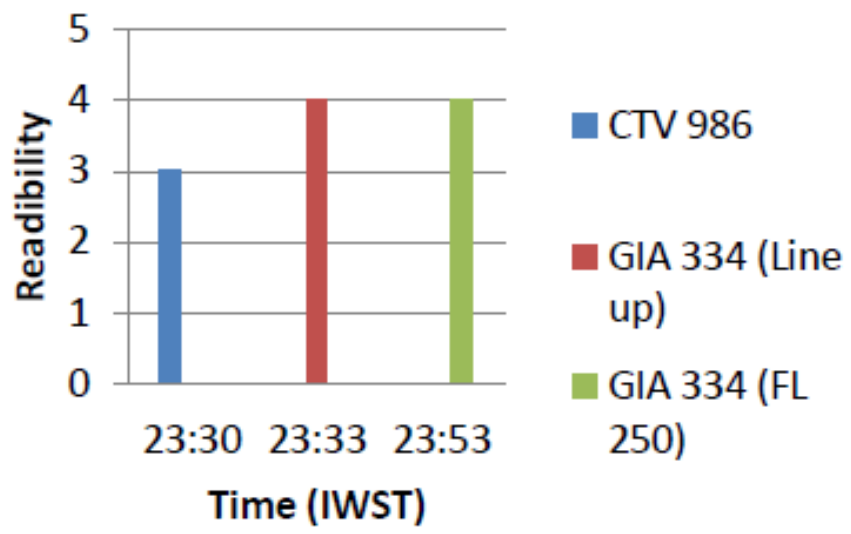

Gambar 6. Pengecekan 1 - Readibility (level) Performa VHF-A/G pada 3 Pesawat

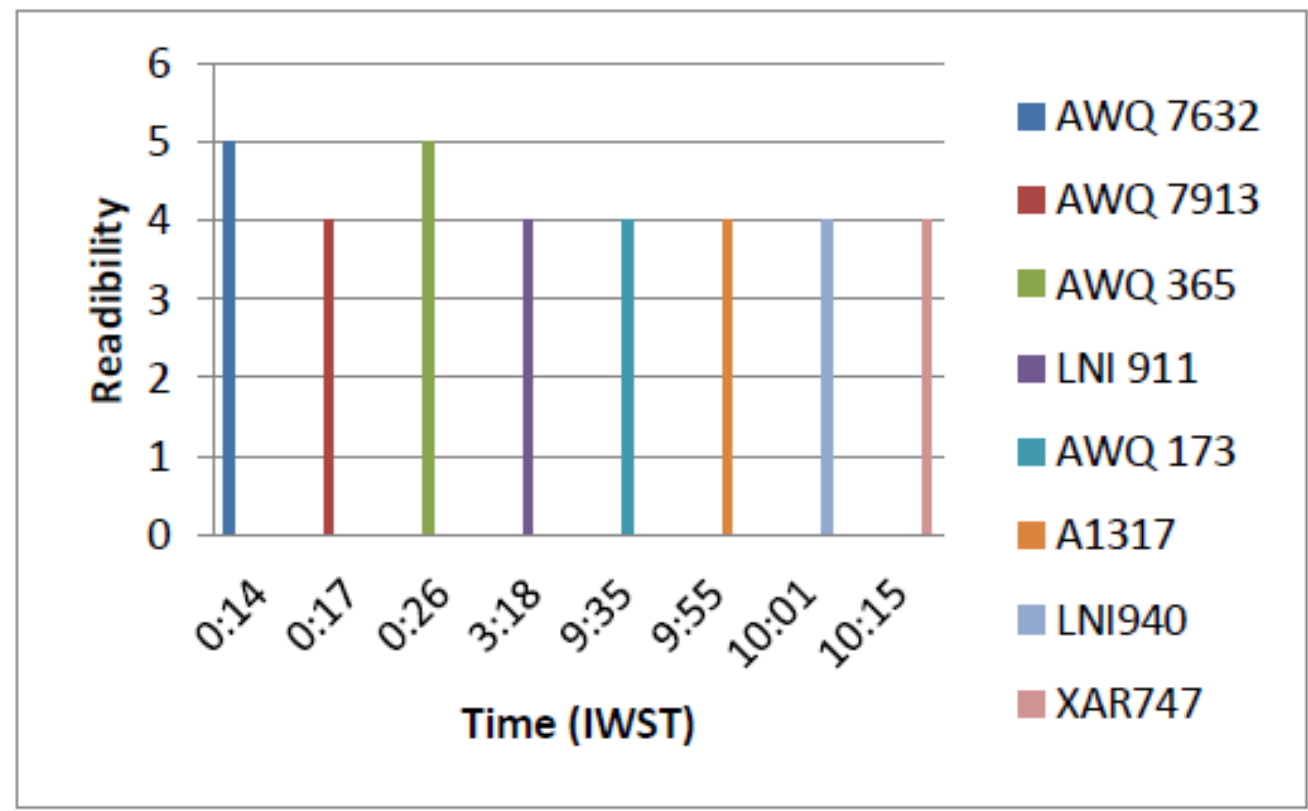

Gambar 7. Pengecekan 2 - Readibility (level) Performa VHF-A/G pada 8 Pesawat 


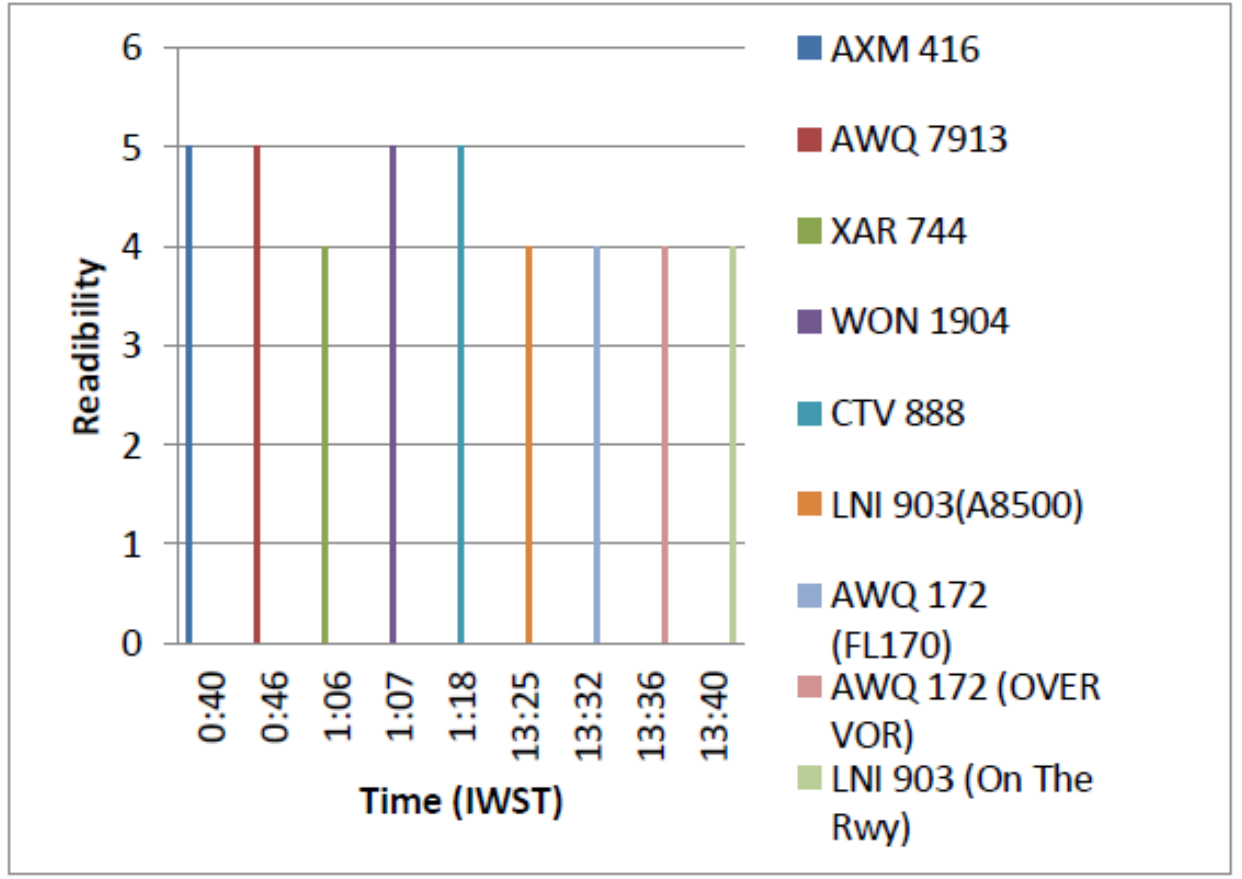

Gambar 8. Pengecekan 3 - Readibility (level) Performa VHF-A/G pada 9 Pesawat

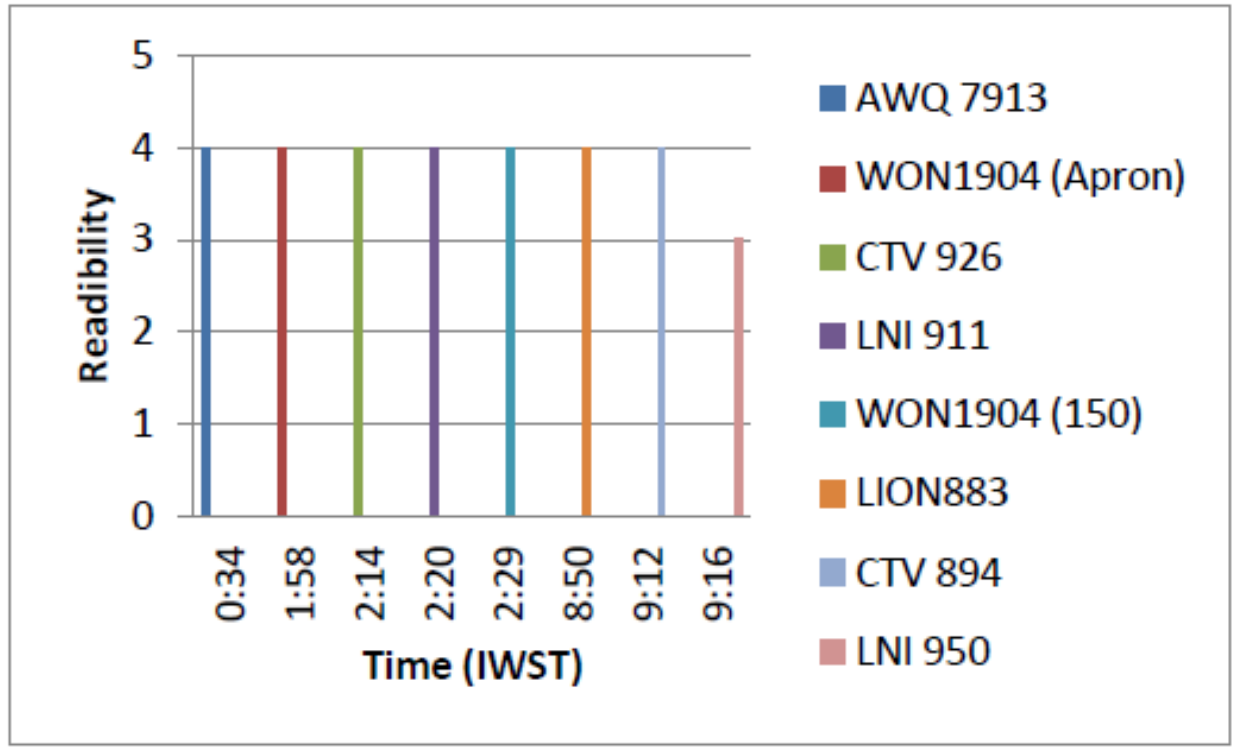

Gambar 9. Pengecekan 4 - Readibility (level) Performa VHF-A/G pada 8 Pesawat

Keterangan:

1. CTV $986,888,926,894$

: Citylink Air

2. GIA 334

: Garuda

3. AWQ $7632,7913,365,173,172$

: Air Asia

4. LNI $911,940,903,883,950$

: Lion Air

5. A1317

: Auri (Pesawat Militer)

6. XAR 747,744

: Express Air

7. AXM 416

: Red Cap Air

8. WON 1904

: Wings Air

ISSN (e): 2540-9123

ISSN (p): 2502-1982 
Pengecekan performa perangkat VHF-A/G antara pilot di pesawat dengan ATC, supaya terjalin komunikasi yang baik, digunakan sebuah indikator level yang biasa disebut readability.

Jika level penerimaannya terbaca 1 atau 2 artinya kondisi perangkat buruk sekali, komunikasi yang terjadi antara kontroler/pemandu lalu lintas (ATC) yang berada di ADC/TOWER dengan pilot di pesawat tidak dapat menerima informasi yang disampaikan dengan jelas. Namun hal ini jarang terjadi, jika sudah mencapai keterbacaan 1 atau 2, maka alat VHF-A/G tidak akan digunakan kembali karena dapat membahayakan proses penerbangan dan menghambat komunikasi yang terjadi.

Jika level penerimanya terbaca 3, suara masih bisa terdengar tetapi masih terdapat noise, hal ini dapat disebabkan karena komponen penyusun alat penerimaan VHF-A/G di dalam pesawat kondisinya kurang baik. Sedangkan untuk level penerimaan yang terbaca 4 dan 5 komunikasi yang dilakukan antara ATC dengan pilot pada pesawat sudah baik, komunikasi antar keduanya jelas terdengar.

\section{Kesimpulan}

1. Untuk melakukan komunikasi antara pilot di dalam pesawat baik dalam posisi (lepas landas, di udara, maupun pendaratan) dengan ATC diatur pada frekuensi $118-137 \mathrm{MHz}$.

2. Daya yang dipancarkan oleh antena VHF-A/G ke pesawat ketika berada di wilayah ADC/TOWER kisaran 25-30 Watt dan ketika pesawat berada di wilayah APP kisaran 30-50 Watt.

3. Pada ketinggian $0-10000 \mathrm{ft}$ pengontrolan kinerja komunikasi dari ATC pada VHF-A/G di wilayah ADC/TOWER dapat dilakukan sedangkan pada ketinggian lebih dari 10000 $\mathrm{ft}$ hingga $20000 \mathrm{ft}$ pengontrolan diambil alih oleh bagian APP.

4. Batas jarak jangkau kontrol komunikasi yang dapat terjadi yaitu pada $0-40 \mathrm{Nm}$ untuk wilayah ADC/TOWER dan $40-87 \mathrm{Nm}$ untuk wilayah APP.

5. Dalam penggunaan perangkat VHF-A/G, untuk melakukan komunikasi dengan baik antara pilot di pesawat dengan ATC diukur dengan indikator level yang menunjukkan kondisi perangkat VHF-A/G dibagian pengirim dan penerima diperoleh nilai readability (keterbacaan) 4 dan 5.

\section{Ucapan Terima Kasih}

Penulis mengucapkan terima kasih kepada Bapak Supriyanto selaku Junior Manager AirNav Indonesia Distrik Bandung yang telah memberikan kesempatan dalam melaksanakan kegiatan penelitian ini. Kepada seluruh pihak AirNav Indonesia Bandar Udara Husein Sastranegara Bandung, ATS Engineering Supervisor, dan Para Teknisi yang tidak dapat disebutkan satu per satu penulis mengucapkan terima kasih atas bimbingan, masukan dan saran, serta pengetahuan seputar komunikasi penerbangan yang telah diberikan.

\section{Daftar Pustaka}

[1] Grumman, N. (2009). T6R VHF Receiver User Documentation. Park Air System: UK.

[2] Grumman, N. (2009). T6T VHF Transmitter User Documentation. Park Air System: UK

[3] Bernhard Haindl, Frequentis AG. (2007). An Independent Technology Assessment for A Future Aeronautical Communication System Based On Potential Systems like B-VHF. 26th Digital Avionics Systems 4.D.6-1

[4] Ho Dac Tu, Shimamoto Shigeru. (2009). A Proposal of Wide-Band Air-to-Ground Communication at Airports Employing 5-GHz Band. Waseda University: Tokyo - Japan

[5] Vergara, W.C. VHF Air-Ground Propagation Far Beyond the Horizon and Tropospheric Stability. Antennas and Propagation: IRE

[6] Tim. (2013). Profil Perusahaan Airnav Indonesia. Dikutip pada tanggal 22 Juli 2017 dari http://www.airnavindonesia.co.id 
[7] Pangaribuan, Davin F. (2016). OJT Teknik Telekomunikasi dan Navigasi Udara Angkatan IX. Medan: Akademi Teknik dan Keselamatan Penerbangan hal (4-11). 